\title{
Peran Trombomodulin untuk Mendeteksi Kerusakan Sel Endotel pada Malaria Tropika dan Malaria Tertiana
}

\author{
Max F.J.Mantik*, T.H.Rampengan*, Mariane B.Ch.Kilis*, Josef S.B.Tuda** \\ * Bagian Ilmu Kesehatan Anak Fakultas Kedokteran Universitas Sam Ratulangi/RSU Prof.Dr.R.D.Kandou, \\ Manado, Sulawesi Utara. \\ ** Bagian Parasitologi Fakultas Kedokteran Universitas Sam Ratulangi, Manado, Sulawesi Utara
}

\begin{abstract}
Latar belakang. Trombomodulin(TM) adalah reseptor sel endotel untuk trombin. Pada penyakit malaria tropika dan malaria tertiana, TM disekresi sesudah kerusakan sel-sel endotel yang terinfeksi P.falciparum atau P.vivax.

Tujuan. Mengetahui apakah TM dapat mendeteksi kerusakan sel endotel pada malaria tropika atau malaria tertiana dan apakah TM berhubungan dengan berat ringan malaria tropika?

Metode. Penelitian menggunakan metode analitik potong lintang, di lima RS di provinsi Sulawesi Utara, Juni-September 2006 pada kasus malaria tropika/malaria tertiana umur 2 tahun-13 tahun. Pemeriksaan TM secara ELISA menggunakan kit Fujirebio TM (FU/ml). Analisis data dengan uji $\mathrm{t}$ independen dan koefisien korelasi Spearmen Rank.

Hasil. Tiga puluh pasien malaria tropika (TM 0,060-0,180FU/ml), 2 pasien malaria tertiana (TM 0,0680,075FU/ml). Uji t terdapat perbedaan bermakna TM pada malaria tropika dan malaria tertiana $(\mathrm{p}=\mathbf{0 , 0 4 4})$. Malaria berat 11 penderita (TM 0,086-0,162 FU/ml). Uji t terdapat perbedaan sangat bermakna TM pada malaria tropika dengan komplikasi dan tanpa komplikasi (p=0,009). Uji Spearmen Rank TM berhubungan positif bermakna dengan derajat parasitemia $\left(r_{s}=0,686, p=0,001\right)$.

Kesimpulan. Trombomodulin dapat digunakan untuk mendeteksi kerusakan sel endotel, TM pada malaria tropika lebih tinggi dari malaria tertiana dan tm berbeda bermakna pada malaria tropika dengan komplikasi dan tanpa komplikasi serta berhubungan bermakna dengan derajat parasitemia. (Sari Pediatri 2007; 9(3):167172).
\end{abstract}

Kata kunci: Malaria tropika, malaria tertiana, hiperparasitemia, trombomodulin.

Alamat korespondensi

Dr. Max F.J.Mantik, SpA(K).

Bagian Ilmu Kesehatan Anak Fakultas Kedokteran Universitas Sam Ratulangi/RSU Prof.Dr. R.D. Kandou, Manado

Telp: 0431-821652; Fax:0431-859091 Email: ikarsup@telkom.net

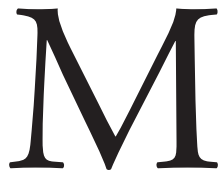
alaria merupakan penyakit infeksi yang paling sering dijumpai di negara sedang berkembang pada kawasan tropik dan subtropik. Di Indonesia malaria masih merupakan masalah kesehatan masyarakat terutama 
di Indonesia bagian timur termasuk di Sulawesi Utara. ${ }^{1}$ Di Bagian Ilmu Kesehatan Anak RSU. Prof.Dr.R.D. Kandou, Manado dari tahun 2002-2004 jumlah kasus Malaria yang dirawat 266 pasien (145 anak laki-laki, 121 anak perempuan). ${ }^{2}$

Trombomodulin (TM) adalah reseptor sel endotel untuk trombin dan didistribusi secara luas di atas permukaan sel endotel, serta ditemukan dalam sirkulasi plasma dan serum. ${ }^{3-5}$ Trombomodulin ini meningkat pada malaria tropika dan malaria tertiana, diabetes mellitus, lupus eritematosus sistemik, penyakit Kawasaki, gromerulonefritis akut dan disseminated intravascular coagulation. ${ }^{6-9}$

Ohnishi dkk, ${ }^{3}$ mendapatkan bahwa TM disekresi setelah terjadi kerusakan seluler sel endotel. Kerusakan sel endotel terjadi oleh karena interaksi antara eritrosit yang terinfeksi dan yang tidak terinfeksi pada kasus malaria tropika dan malaria tertiana. Belum jelas diketahui perbedaan peningkatan kadar TM pada malaria tropika dan malaria tertiana.

Kegawatan infeksi plasmodium malaria tergantung pada seberapa besar kemampuan eritrosit yang terinfeksi melekat pada endotel dan yang membentuk roset dengan eritrosit yang tidak terinfeksi. ${ }^{8,10-12}$ Timbul pertanyaan, apakah kemampuan parasitized red blood cells (PRBC) yang melekat pada reseptor merupakan faktor penting terjadinya malaria yang lebih berat dan apakah kadar TM dapat menggambarkan derajat berat penyakit malaria.

Tujuan penelitian untuk mengetahui apakah TM dapat digunakan untuk mendeteksi kerusakan sel endotel pada malaria tropika atau malaria tertiana dan untuk mengetahui apakah TM berhubungan dengan derajat berat penyakit.

\section{Metode}

Penelitian dilakukan di lima rumah sakit di provinsi Sulawesi Utara yaitu RSU Prof.Dr.R.D.Kandou, RSU Pancaran Kasih, RS Tentara Teling, RSUD Noongan dan RSU Budi Setia Langowan dari bulan Juni sampai September 2006. Populasi penelitian adalah semua pasien dengan diagnosis tersangka malaria klinis usia 2 tahun sampai 13 tahun yang berobat di poliklinik anak dan yang dirawat inap di rumah sakit penelitian. Sampel penelitian ini adalah pasien yang memenuhi kriteria inklusi yaitu usia 2 tahun - 13 tahun, dan orang tua/wali menyutujui untuk ikut dalam penelitian, kriteria eksklusi apabila menderita penyakit Kawasaki, lupus eritematosus sistemik, gromerulonefritis akut, disseminated intravascular coagulation, diabetes mellitus dan mixed malaria. Besar sampel penelitian minimal 24 anak.

Pemeriksaan TM dengan sistem ELISA menggunakan kit Fujirebio TM $(\mathrm{FU} / \mathrm{ml}) .{ }^{13}$ Darah $2 \mathrm{ml}$ dimasukkan dalam tabung EDTA, disentrifuse selama 10 menit pada 2500 grafitasi (g). Sampel plasma dimasukkan dalam sumur mikro, kemudian diencerkan dengan reagen TM dan dibaca dengan alat mikroplate reader: $490 \mathrm{~nm}$ filter. Hasil dinyatakan dengan satuan $\mathrm{FU} / \mathrm{ml}$ (Fujirebio). Data dianalisis dengan uji t independen dan dengan koefisien korelasi Spearmen Rank.

\section{Hasil}

Didapatkan 75 kasus tersangka malaria klinis yang dirawat di rumah sakit tempat penelitian terdiri dari 43 kasus dengan hasil pemeriksaan tetes darah tebal negatif dan 32 kasus positif, terdiri dari 30 kasus dengan P.falciparum (malaria tropika) dan 2 penderita dengan P.vivax (malaria tertiana). Karakteristik pasien malaria tropika dan malaria tertiana tertera pada Tabel 1 .

Hasil pemeriksaan kadar TM pada 30 pasien malaria tropika dan 2 penderita malaria tertiana didapatkan rentang nilai TM 0,060 - 0,180 FU/ml. Perbedaan kadar TM untuk mendeteksi kerusakan sel endotel dengan malaria tropika dan malaria tertiana (Tabel 2) hasil uji t menunjukkan perbedaan bermakna $(\mathrm{p}=0,044)$.

Kadar TM pada berbagai derajat parasitemia pada malaria tropika tertera pada Tabel 3.

Hubungan antara derajat parasitemia pada malaria tropika dengan kadar TM untuk mendeteksi kerusakan sel endotel yang dianalisis berdasarkan hasil uji Spearman'r rho diperoleh $\mathrm{r}_{\mathrm{s}}=0,686$ dengan $\mathrm{p}=0,001$. Hasil tersebut menunjukkan terdapat hubungan positif yang bermakna antara peningkatan derajat parasitemia pada malaria tropika dengan kadar TM untuk mendeteksi kerusakan sel endotel. Secara grafik hubungannya tertera pada Gambar 1 .

Distribusi malaria tropika dengan komplikasi dan tanpa komplikasi yaitu $19(63,33 \%)$ malaria tanpa komplikasi, 1 (3,33\%) malaria serebral, 2 (6,67\%) anemia berat, dan $8(26,66 \%)$ parasitemia berat.

Hasil pengujian perbedaan TM untuk mendeteksi 
Tabel 1. Karakteristik pasien malaria tropika dan malaria tertiana

\begin{tabular}{lcc}
\hline Karakteristik & $\begin{array}{c}\text { Malaria Tropika } \\
\mathrm{n}(\%)\end{array}$ & $\begin{array}{c}\text { Malaria Tertiana } \\
\mathrm{n}(\%)\end{array}$ \\
\hline Laki-laki & $18(60,00)$ & 0 \\
Perempuan & $12(40,00)$ & $2(100,00)$ \\
Umur (tahun) & $2,17-12,33$ & $4,33-6,75$ \\
Gambaran Klinis & & \\
Nyeri perut & $27(90,00)$ & 0 \\
& & $2(100,00)$ \\
Nyeri kepala & $21(70,00)$ & $1(50,00)$ \\
& & $1(50,00)$ \\
Mual/muntah & $25(83,33)$ & $1(50,00)$ \\
& & $1(50,00)$ \\
Konjungtiva & $14(46,67)$ & $2(100,00)$ \\
Anemis & $1(3,33)$ & 0 \\
Sklera ikterus & & $2(100,00)$ \\
& $22(73,33)$ & 0 \\
Hepatomegali & & $2(100,00)$ \\
& $9(30,00)$ & 0 \\
Splenomegali & & $2(100,00)$ \\
& & 0 \\
Laboratorium & $4,4-13,2$ & $11,7-12,5$ \\
Hemoglobin $(\mathrm{gr} \%)$ & $2.000-13.500$ & $3.400-11.500$ \\
Leukosit $\left(\mathrm{mm} /{ }^{3}\right)$ & $14,9-39,4$ & $33,9-37,7$ \\
Hematokrit $(\%)$ & $2900-332.000$ \\
Trombosit $\left(\mathrm{mm} /{ }^{3}\right)$ & $39.000-448.000$ & 2.900 \\
\hline
\end{tabular}

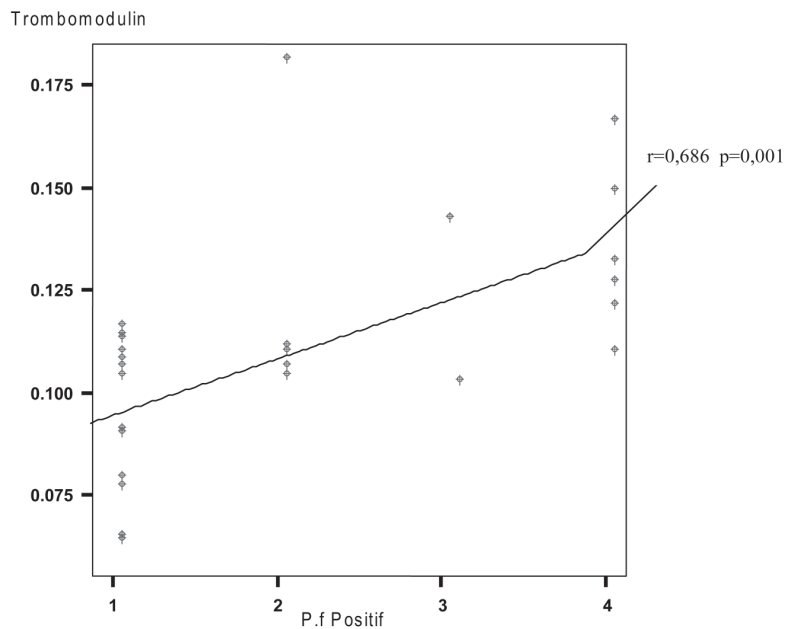

Gambar 1. Hubungan kadar trombomodulin dengan derajat parasitemia pada malaria tropika

kerusakan sel endotel pada malaria tropika dengan komplikasi dan tanpa komplikasi tertera pada Tabel 4. Hasil uji t menunjukkan perbedaan yang bermakna $(\mathrm{p}=0,009)$.
Tabel 2. Perbedaan kadar trombomodulin pada penderita malaria tropika dan malaria tertiana

\begin{tabular}{lccccccc}
\hline Malaria & $\mathrm{n}$ & Min & Maks & Rerata & SB & Uji t & $\mathrm{p}$ \\
\hline $\begin{array}{l}\text { Malaria } \\
\text { Tropika }\end{array}$ & 30 & 0,060 & 0,180 & 0,1054 & 0,0267 & & \\
$\begin{array}{l}\text { Malaria } \\
\text { Tertiana }\end{array}$ & 2 & 0,068 & 0,075 & 0,0715 & 0,0049 & & \\
\hline
\end{tabular}

Tabel 3. Kadar trombomodulin berdasarkan derajat parasitemia malaria tropika

\begin{tabular}{lccccc}
\hline \multirow{2}{*}{$\begin{array}{c}\text { Derajat } \\
\text { parasitemia }\end{array}$} & & & & & \\
\cline { 2 - 6 }$(\%)$ & Min & Maks & Rerata & SB \\
\hline Pf + & $17(56,67)$ & 0,060 & 0,112 & 0,09088 & 0,017150 \\
Pf ++ & $5(16,67)$ & 0,100 & 0,180 & 0,11900 & 0,034220 \\
Pf +++ & $2(6,66)$ & 0,104 & 0,138 & 0,12100 & 0,024042 \\
Pf ++++ & $6(20,00)$ & 0,106 & 0,162 & 0,13017 & 0,02233 \\
\hline Jumlah & $30(100,00)$ & 0,060 & 0,180 & 0,10543 & 0,026710 \\
\hline
\end{tabular}

Tabel 4. Perbedaan kadar trombomodulin pada malaria tropika dengan komplikasi dan tanpa komplikasi

\begin{tabular}{|c|c|c|c|c|c|}
\hline Malaria tropika & $\mathrm{n}$ & Rerata & SB & $\mathrm{t}$ & $\mathrm{p}$ \\
\hline si & 19 & 0,09689 & 974 & $-2,50$ & 0,009 \\
\hline Dengan komplikasi & 11 & 0,12018 & 0,021835 & & \\
\hline
\end{tabular}

\section{Diskusi}

Sel endotel merupakan sel yang melapisi lumen pembuluh darah serta mampu untuk menangkap perubahan hemodinamika dan sinyal-sinyal dari darah. ${ }^{14-16}$ Reseptor pada sel endotel yaitu P-selectin, vascular Cell adhesion molecule-1 (VCAM-1), intercellular cell adhesion molecule-1 (ICAM-2), endothelial leucocyte adhesion molecule-1 (ELAM-1), thrombomodulin (TM), platelet glycoprotein IV (PG IV), chondroitin sulfate-A (CSA), platelet endothelial cell adhesion molecule-1 (PECAM-1). ${ }^{4,17-20}$

Kerusakan sel endotel dapat terjadi pada penyakit diabetes mellitus, disseminated intravascular coagulation, penyakit kawasaki, glomerulonefritis akut, lupus eritematosus sistemik, malaria tropika dan malaria tertiana. Kerusakan sel endotel pada penyakit-penyakit ini dapat diketahui dengan peningkatan trombomodulin. ${ }^{3,4,6-9}$ 
Trombomodulin merupakan glikoprotein transmembran terdiri dari 557 asam amino pada permukaan sel endotel. Rangkaian TM terdiri dari $N$ terminal lektin-like, six epidermal growh factor (EGF), serin-threonine-rich ( $N$ - dan O-glycosylation), transmembrane, dan cytoplasmic tail.6,21-24 TM mempunyai beberapa EGF pengulangan, EGF5 dan 6 bertanggung jawab atas afinitas pengikatan trombin $\left(\mathrm{K}_{\mathrm{d}}=0,5 \mathrm{~nm}\right)$, EGF 4 bertanggung jawab atas pengikatan protein C. ${ }^{4}$ Pada rantai B trombin terdapat suatu domain, yang dapat dibedakan dengan situs katalitik aktif, yang disebut exosite I yang terikat dengan anion (anion-binding exosite I) yang terlibat dalam pengikatan trombin padaTM. ${ }^{21,22}$

Trombomodulin adalah reseptor permukaan sel endotel untuk trombin, fungsi TM mengubah protein $C$ yang terikat pada trombin menjadi aktivator protein C. Setelah protein $\mathrm{C}$ teraktivasi, maka TM bekerja sebagai antikoagulan utama lewat kemampuannya menginaktivasi berbagai faktor pembekuan (Va, VIIIa, Xa dan XIIIa). Aktivasi protein C merupakan hal yang sangat penting dalam meregulasi proses koagulasi dan reaksi inflamasi. Setelah teraktifasi, protein C merupakan antikoagulan dan protease anti-inflamasi yang kuat. ${ }^{2,5,23,24}$

Kadar TM normal dalam plasma darah belum bisa ditegakkan dengan pasti. Nilai kadar trombomodulin dari $0-10 \mathrm{FU} / \mathrm{ml} .{ }^{13}$ Pada kadar yang di atas normal, TM telah dipandang sebagai petanda adanya cedera sel endotel. ${ }^{17}$

Kegawatan infeksi malaria tergantung sebagian besar pada kapasitas eritrosit yang terinfeksi P.falciparum untuk melekat pada endotel dan membentuk roset dengan sel-sel. Aktivasi dari sel endotel yang diakibatkan oleh adhesi eritrosit yang terinfeksi menimbulkan pengeluaran yang berlebihan dari reseptor endotel. Sebagian reseptor di permukaan sel endotel ialah trombomodulin (TM), thrombospondin (TSP), $\mathrm{CD}_{36}$, ICAM-1, E-selectin, VCAM-1, PECAM-1, P-selectint berinteraksi dengan eritrosit yang terinfeksi parasit (PRBC) melalui PECAM-1., ${ }^{6,13,21,22}$

Ohnishi $\mathrm{dkk}^{3}$ melakukan penelitian di Jepang pada 6 pasien malaria tertiana dengan menghubungkan serum TM, ICAM-1, VCAM-1, E-selectin. Terdapat hubungan yang antara serum TM antara kelompok malaria tertiana dengan kelompok kontrol $(\mathrm{p}<0,005)$. Serum TM yang meningkat pada penelitian mereka dapat disebabkan oleh kerusakan sel endotel oleh karena interaksi antara eritrosit yang terinfeksi dan yang tidak terinfeksi pada sel endotel. Diketahui bahwa baik eritrosit yang terinfeksi maupun tidak terinfeksi pada kelompok Malaria tropika dengan angka sekuestrasi lebih tinggi pada kasus berat. Rangkaian CSA dan TM merupakan reseptor untuk eritrosit yang terinfeksi P.falciparum, eritrosit yang terinfeksi p.falciparum terikat pada TM, ICAM, selectin-E di permukaan sel endotel mungkin merupakan salah satu dari sebab sekuestrasi. Sekuestrasi yang ringan mungkin juga terjadi dalam pembuluh darah kasus malaria tertiana, dan sekuestrasi berperan menyebabkan cedera pada sel endotel pada pasien dalam penelitian mereka. Dengan demikian peningkatan TM menunjukan kerusakan sel endotel terjadi dalam tahap akut pada malaria tertiana.

Muanza dkk, ${ }^{25}$ melakukan penelitian malaria tropika di Thailand pada 17 pasien, bertujuan untuk mengetahui hubungan reseptor CSA, ICAM-1, VCAM-1 dan E-selektin dengan derajat berat malaria tropika. Terdapat hubungan antara CSA dengan derajat berat malaria.

Pada penelitian ini kadar TM yang diperiksa dengan sistem ELISA pada 30 kasus malaria tropika, diperoleh rentang nilai TM 0,180-0,160 FU/ml dan 2 kasus malaria tertiana didapatkan rentang nilai TM 0,075-0,068 FU/ml. Pada malaria tropika rerata TM 0,1054 FU/ml dengan SB TM 0,0267 FU/ml dan pada malaria tertiana rerata TM 0,0715 FU/ml dengan SB TM 0,0049 FU/ml. Perbedaan kadar TM untuk mendeteksi kerusakan sel endotel pada malaria tropika dan malaria tertiana yang dianalisis berdasarkan uji t, ternyata terdapat perbedaan bermakna antara kadar TM pada malaria tropika dan malaria tertiana $(\mathrm{p}=0,044)$. Hasil penelitian in vitro Rogerson $\mathrm{dkk}^{9}$ pada 148 pasien malaria tropika didapat kadar TM meningkat pada 23 anak.

Derajat parasitemia malaria tropika diperiksa secara semi kuantitatif dan hubungan antara derajat parasitemia pada malaria tropika dengan kadar TM untuk mendeteksi kerusakan sel endotel yang dianalisis berdasarkan uji Spearman'r rho diperoleh $r_{s}=0,686$ dengan $p=0,001$. Hasil ini menunjukkan terdapat hubungan positif yang sangat bermakna antara peningkatan derajat parasitemia pada malaria tropika dengan kadar TM untuk mendeteksi kerusakan sel endotel (Gambar 2). Semakin tinggi derajat parasitemia semakin tinggi pula kadar TM. Kegawatan infeksi malaria tergantung sebagian besar pada kapasitas eritrosit yang terinfeksi P.falciparum 
untuk melekat pada endotel dan membentuk roset dengan sel-sel. Aktivasi dari sel endotel yang diakibatkan oleh adhesi eritrosit yang terinfeksi mengakibatkan TM berlebihan keluar dari permukaan sel endotel. ${ }^{6,13,21,22}$

Pada penelitian ini, hasil uji t menunjukkan perbedaan kadar TM untuk mendeteksi kerusakan sel endotel antara malaria tropika dengan komplikasi dan tanpa komplikasi $(\mathrm{p}=0,009)$. Penelitian ini hampir sama hasilnya dengan penelitian yang dilakukan Rogerson dkk, ${ }^{9}$ di Malawi pada 155 anak. Pada kelompok kasus dengan malaria berat yaitu malaria serebral (38), anemia berat (22) dengan kelompok kontrol terdapat hubungan dengan kadar TM.

Pada malaria berat eritrosit yang terinfeksi P.falciparum akan mengalami proses sekuestrasi, selain itu permukaan eritrosit yang terinfeksi akan membentuk knop yang berisi antigen P.falciparum. Saat terjadi proses sitoadherensi knob berikatan dengan reseptor sel endotel, akibatnya terjadi obstruksi pembuluh darah kapiler yang menyebabkan iskemia jaringan. Terjadi sumbatan ini didukung pula dengan terbentuknya rosette. ${ }^{10,11,26-28}$

\section{Kesimpulan}

Dapat disimpulkan bahwa trombomodulin dapat digunakan untuk mendeteksi kerusakan sel endotel pada malaria, TM pada malaria tropika lebih tinggi daripada malaria tertiana. Terdapat perbedaan antara TM pada malaria tropika dengan komplikasi dan tanpa komplikasi serta TM berhubungan dengan derajat parasitemia.

\section{Daftar Pustaka}

1. Rampengan TH. Malaria. Dalam: Rampengan TH, Laurenz IR, editor. Penyakit infeksi tropik pada anak. Cet.2. Jakarta: Penerbit Buku Kedokteran EGC; 2004. h. 185-204.

2. Kilis MB, Rampengan NH, Julianto F, Rampengan TH. Thrombocytopenia as prognostic value in malaria Falciparum. Abstrak KONIKA XIII, Bandung: 4-7 Juli 2005; Bandung.

3. Ohnishi K. Serum level of thrombomodulin, intercellular adhesion, moleculle-1, vaskuler cell adhesion moleculle-01, and E-selectin in acute phase of plasmo- dium vivax malaria. Am.J.Trop.Med Hyg 1999;60:24850 .

4. Weiler H, Iserman BH. Thrombomodulin. J.Throm Haemost 2003;1:1515-24.

5. Mantik MFJ. Gangguan koagulasi. Sari Pediatri 2004 (Suppl I); 6:60-7.

6. Uehara S, Gotot K, Handa K. Separation and characterization of the molecular species of thrombomodulin in the plasma of diabetic patients. Thrombosis research 2001:104;325-32.

7. Barsoum R. Malaria acute renal failure. J.Am Soe Nephrol 2000;11:2147-54.

8. White N, J. Malaria. Dalam: Gordon C, Zumla A. Manson's tropical disease. Edisi ke-21. WB. Saunder; 2003. h. 1205-79.

9. Rogerson SJ, Tembenu R, Dobano C, Plitt S, Taylor TE, Molyneux ME. Cytoadherence characteristics of plasmodium falciparum-infected erythrocytes from Malawian children with severe and uncomplicated malaria. Am.J.Trop.Med.Hyg 1999;61:467-72.

10. World Health Organization. Severe falciparum malaria. Trans R Soc Trop Med Hyg 2000; 94(supp 1):S1/1-90.

11. Maitlain K, Marsh K. Pathophysiology of severe malaria in children. Acta Tropica 2004;90: 13-40.

12. Satpathy SK, Mohanty N. Severe falciparum malaria. Indian J Pediatr 2004;71:133-5.

13. Fujirebio Thrombomodulin Elisa Kit. Didapat dari: http://www.fujirebiocustomerservice@di.com. Pada tanggal 17 Juni 2006.

14. Soeatmadji JW. Pemeriksaan-pemeriksaan untuk deteksi disfungsi endothelial. Forum diagsnosticum 2000;4:111.

15. Histology and histopathology cellular and molecular biology. Didapat dari: http://www.bmjjournals.com. [pada tanggal 6 Februari 2006]

16. Blood vessels [cited 9 Jun 2006]. Didapat dari: http:// www.greenfiel.fortunecity.com.

17. Cines DB, Pollsak E, Buck CA. Endothelial cells in physiology and in the pathophysiology of vascular disorder. Blood 1998;91:3521-50.

18. Ishii H, Kazame M, Uchiyama H. Soluble thrombomodulin antigen in conditional medium is increased by damage of endothelial cells. Throm Haemost 1991; 65: 618-23.

19. Handin R. Disorders of the platelet and vessel wall. Dalam: Kasper DL, Fanci AS, Longo DL, penyunting. Horison's principles of internal medicine vol I. Edisi ke16. New York: McGraw-Hill; 2005. h. 673-4.

20. Maruyama I, Bell EC, Majerus PW. Thrombomodulin 
is found on endothelium of arteries, veins, capillaries, and lymphatics, and on syncytiotrophoblast of human placenta. J cell Biol 1985;101:363-71.

21. Gale M, Griffin JH. Characterization of a thrombomodulin binding site on protein $\mathrm{C}$ and its comparison to an activated protein $\mathrm{C}$ binding site for factor VA. Proteins 2004;54:433-41.

22. Fruentes-Prior P, Iwanaga Y, huber R, Pagila R, Rumennik G, Seto M, dkk. Structural basis for the anticoagulant activity of the thrombin-trombomodulin complex. Nature 2000; 404:518-24.

23. Dahlback B, Villouttreix BO. Molecular regognition in the protein $\mathrm{C}$ anticoagulant pathway. J.Throm Haemost
2003;1:1525-34.

24. Ohlin AK, Hausson M, Larsson K. Soluble thrombomodulin activity and soluble thrombomodulin antigen in plasma. J.Thromb Haemost 2005;3:976- 82.

25. Muanza K, Traore BK. Circulating, reseptor impicated in the cyto-adherence occurring in severe plasmodium falciparum malaria in Thailand. Didapat dari: http:// www. ingentacoment.com. [pada tanggal 7 Mei 2006]

26. Path MK, Mark K. Pathophysiology of severe malaria in children. Acta tropica 2004;90:131-40.

27. Clark IA, Lawden WB. The pathophysiology of falciparum malaria. Pharmacol ther 2003,99: 22160 . 